\title{
International Competitiveness of Export-oriented Industries in Bulgaria
}

\author{
Antoaneta Vassileva, Vasil Petkov, Paskal Zhelev \\ University of National and World Economy, Sofia, Bulgaria
}

\begin{abstract}
With increasing globalization and Bulgaria's accession into the European Union (EU), the question how to improve the country's international competitiveness has become very important and urgent. The aim of the paper is to present the results of a research on the past decade's competitiveness of Bulgarian export-oriented sectors, enjoying good positions in local and international markets and having a high development potential. The first part of the article presents a comprehensive review of the concept of competitiveness - its definitions, factors, and measurements at national, industry, and firm level. On the basis of the theoretical considerations, an empirical analysis on the current state of competitiveness of the selected export-oriented industries is performed. These include metallurgy, machine building, chemicals, clothing and textiles, furniture, wine production, tobacco, and food processing. The research answers the following questions: What are the major competitive advantages of Bulgarian export-oriented industries on the world market? What are their disadvantages? How did they change over the period 2002-2012, and what steps should be taken to meet the challenges? The employed methods of analysis are both quantitative - calculating various production, trade, and price indices, and qualitative - carrying out a survey among top managers of firms operating in the selected industries across all the regions of the country. Results show that the country's competitiveness on international level has gradually improved but still remains at a comparatively low level as Bulgarian producers compete mostly on the price, invest very little in research and development (R\&D), rely on low labor costs, and produce goods with low added value. The paper looks into the specific challenges to competitiveness faced by different sectors and the implications of addressing them. In conclusion, it puts forward some recommendations for boosting Bulgaria's international competitiveness which are aimed at key stakeholders: companies, central and local government, and institutions promoting cooperation.
\end{abstract}

Keywords: export competitiveness, industry analysis, competitive advantages, Bulgaria

\section{Introduction}

After the dissolution of the former Eastern bloc, Bulgaria has started a process of transition to a market economy and fast integration in the world economy. In the course of this process, a deep structural

\footnotetext{
Antoaneta Vassileva, Ph.D., Professor, International Economic Relations and Business Department, University of National and World Economy.

Vasil Petkov, Ph.D., Assistant Professor, International Economic Relations and Business Department, University of National and World Economy.

Paskal Zhelev, Ph.D., Assistant Professor, International Economic Relations and Business Department, University of National and World Economy.

Correspondence concerning this article should be addressed to Vasil Petkov, Students Town, UNWE, office 3030, 1700 Sofia, Bulgaria.E-mail: vasil1979@yahoo.com.
} 
transformation was carried out leading to a significant shift in resources from some sectors to others and a complete change in the environment for doing business. These changes offer Bulgaria huge potential for significantly increased productivity of production factors and greater access to new resources and markets, but also pose a significant risk of economic retardation. To meet the challenges of economic transformation, European integration, and ever increasing globalization, the issue of the ability of Bulgaria to compete in the global market, particularly in sectors with good growth prospects bringing high added value comes to the fore. This justifies the great relevance of the need to assess the economic position of the country in terms of its international competitiveness during the last decade in which it became a full member of the EU and has been hit very hard by the global financial and economic crisis.

\section{Research Question}

The aim of the research is to present the results of analysis and assessment of the international competitiveness of Bulgaria's export-oriented industries in the period 2002-2012 and to recommend macro, meso, and micro level measures for its improvement. The paper answers the following questions: What are the major competitive advantages of Bulgarian export-oriented industries on the world market, what are their disadvantages? how did they change over the period 2002-2012? and what steps should be taken to meet the challenges? To this end, the following research tasks are set:

- To make a comprehensive review of the concept of international competitiveness at national, sectoral, and company levels and the most common and relevant indicators for its measurement;

- To identify the sectors with highest export orientation and future potential in Bulgaria;

- To collect, process, and analyze output, export, import, price data, and indices on RCA, RTB, and unit labor costs;

- To design and distribute a questionnaire among firms in the selected industries which include questions related to firms' internal strengths - quality and price of products, used technologies, managerial practices, internationalization strategies, etc.;

- To evaluate the competitive advantages and disadvantages of the sectors under study;

- To formulate conclusions and recommendations to the government, business, and supporting institutions for the improvement of the international competitiveness of Bulgaria's export-oriented industries.

Based on the research tasks set in the paper, the authors have adopted the following structure. The first section of the article analyzes the concept of competitiveness at different level of analysis from theoretical and methodological perspective, outlining the major definitions, factors and indicators for its evaluation. The second part of the paper is devoted to presentation of the results of the performed quantitative and qualitative analysis of the international competitiveness of the selected export-oriented Bulgarian industries. Finally, in the third section of the paper, the conclusions from the study and some policy recommendations, directed at the various stakeholders are put forward.

\section{Analytical Framework}

The study uses a set of general scientific and specific methods of assessing the international competitiveness of Bulgarian export-oriented industries such as analysis and synthesis, abstraction and generalization, induction and deduction, statistical methods, strength, weakness, opportunity, and threat (SWOT) multifactor and comparative analysis. Main sources of information are the Bulgarian National 
Statistical Institute and the Eurostat Directorate-General of the European Commission for secondary data and the specially developed for the project survey carried out among 234 small and medium sized firms in all the regions of Bulgaria for primary data.

\section{Competitiveness-Theoretical and Methodological Aspects}

Growing globalization directs rising attention to national ability to compete in world markets. Despite widespread usage and frequent study, the concept of competitiveness is not defined unambiguously in economics. Competitiveness features implicitly in many theories, yet possesses neither a theoretical basis that would enable analysis, nor a formal conceptual construct. Many authors avoid precise definitions of competitiveness in their studies, leaving readers to interpret it as they would.

The multitude of approaches, definitions, and indicators of competitiveness is partly due to the fact that the concept emerged more in business circles than in theoretical economics. As a category, competitiveness features more in business and management titles than in economics ones.

The first contentious issue related to the concept of competitiveness stems from the level of analysis, i.e., whether the focus falls on companies, economic sectors, regions, or nations. While companies need to be competitive in order to survive and withstand the competitive pressure of market forces, countries cannot declare bankruptcy and cease operations. Thus, the concept of competitiveness is well defined at the micro level as regards companies' ability to survive and improve their market positions vis-à-vis their competitors. At all other levels, however, the objectives of industries, regions, or nations might differ from those of the individual units that make them up. For that reason, any mechanistic stretching of the meaning of competitiveness from the reasonably clear company level to higher levels results in serious defects and over-generalizations that skew any analysis. This is why the selection of a sound concept for measuring competitiveness remains essentially open, with diverse options suitable on a case-by-case basis, depending on the specific thrust and purpose of analyses.

In 1985, the United States (US) Presidential Commission on Industrial Competitiveness formulated one of the most widely used macroeconomic definitions of competitiveness: "A nation's competitiveness is the degree to which it can, under free and fair market conditions, produce goods and services that meet the test of international markets while simultaneously maintaining or expanding the real incomes of its citizens". This definition stresses that the ultimate purpose of competitiveness is to maintain and raise the real income of citizens as reflected in a nation's standard of living. From this perspective, national competitiveness is not an end in itself, but rather a means to an end. It refers to raising national living standards through investment, production, and participation in international trade.

The European Commission gave another popular definition for assessing the overall economic competitiveness of a nation: "the ability of the economy to provide its population with high and rising standards of living and high rates of employment on a sustainable basis" (European Commission, 2001).

The World Economic Forum focuses on similar ground in defining competitiveness as:

The set of institutions, policies, and factors that determine the level of productivity of a country. The level of productivity, in turn, sets the sustainable level of prosperity that can be earned by an economy. In other words, more competitive economies tend to be able to produce higher levels of income for their citizens. (World Economic Forum, 2010-2011, p. 4) 
The idea that economic success depends on competitiveness gained ground in the late 1970s. A nation which lags behind in terms of productivity or technology is deemed likely to experience crisis in the same manner as a company that cannot manage to match its competitors' costs or products. Each nation thus has an interest in creating suitable conditions to attract foreign direct investment (FDI) which would transfer expensive modern technology, create jobs, cut unemployment, and ultimately improve public welfare. Moreover, it is important to create conditions to curb business costs by offering companies and entrepreneurs favorable credit, maintaining currency stability, and low inflation, thus helping make national companies and products competitive domestically and internationally. It could thus be said that, as national competitiveness depends on corporate and sectoral competitiveness, company and sectoral competitiveness, in turn, depends on national competitiveness.

The basis of competitiveness is human resources with their skills, abilities, qualities, educational attainment, etc.. It is people's manner of working and their executive, organizational, and managerial skills that largely determine the degree of efficiency a company brings to its business. The successful integration of companies into the national and international competitive environment and their market strength determine the competitiveness of the sector in which they operate. Technical and technological conditions and political and economic environment in a country and internationally are significant in this respect. Sectoral competitiveness may be assessed by reference to the level of sophistication production that production has attained. National competitiveness depends both on what a state produces and in what amount, and on its international economic and political position and the degree of its infrastructural development (Zaharieva, 2007).

The aforementioned facts may prompt the following conclusions:

(1) Competitiveness is always a comparative category that shows an economy's ability to raise the overall national productivity and quality and to compete with other economies regionally and globally;

(2) National competitiveness is a broad and general concept that includes corporate, sectoral, and regional competitiveness. It intertwines a multitude of aspects such as, inter alia, economic growth, productivity, incomes, technological development, commerce, investment, and human capital, i.e., all those factors on which national prosperity and development depend;

(3) In today's globalizing and integrating world, national competitiveness is as strongly dependent on company competitiveness as company competitiveness is on national competitiveness. In this sense, national competitiveness may be said to depend on:

- The country's trade performance which depends on companies' ability to export and sell goods in international markets at prices providing high incomes;

- Nations' ability to create suitable conditions for attracting foreign investment not only in sectors in which those nations specialize and have comparative advantages, but also in sectors with high added value, alongside stimulating existing sectors;

- Companies' ability to boost productivity by introducing new technology and governments' ability to create suitable conditions for this process;

- Companies' and governments' ability to adapt their policies and strategies to the changing market, economic, and political realities (Zaharieva, 2007).

(4) National competitiveness aims to attain sustainable development combining high economic growth and high living standards while protecting the environment; 
(5) Micro-level competitiveness is synonymous with a firm's long-run profit performance and its ability to offer attractive pay to the employees and high earnings to its owners (Kubiak, 2006).

There are different definitions of competitiveness at the sectoral level. Momaya (1998) considers that it is often regarded as the result of the strategies and actions of companies within a given sector. Moreover, companies and policy makers often downplay the significance of the so-called non-business infrastructure, including educational and training institutions, research bodies and unions. Thus, Momaya sees meso-level competitiveness shaped by interactions between the non-business infrastructure and business firms. Other definitions include:

- The collective ability of firms in that sector to compete internationally (D’Cruz \& Rugman, 1992);

- The extent to which a business sector offers potential for growth and attractive return on investment (IMEDE, 1991).

While the latter definition appears satisfactory from the perspective of an investor, it fails to take into account the interests of a significant proportion of sectoral stakeholders. Identifying key components of the former definitions, Momaya amplifies them to derive a balanced definition of sectoral competitiveness. It represents the extent to which a given business sector:

- Satisfies consumer needs with suitable combinations of the following product characteristics: price, quality, and innovation;

- Satisfies employees' needs, for instance in terms of involvement, benefit programs, training, and safe workplace;

- Offers attractive return on investment;

- Has profitable growth potential (Momaya, 1998).

The authors of these definitions consider that a sector's competitiveness may be inferred by analyzing the performance of that sector's leading companies. They consider competitive that economic sector which comprises internationally competitive companies. Competitiveness measures may be calculated at an industry level if firm-level data are not available. Most of the measures of competitiveness that can be calculated at a firm level can be calculated at an industry level as well. For example, profitability may be measured at an industry level. An industry that consistently earns average or above average rates of return in open competition with foreign suppliers can be regarded as competitive (McFetridge, 1995).

A significant difference between determining competitiveness at a micro and meso level is that, while companies may be assessed through comparison with local competitors, sectors have to be assessed by comparisons with analogous industries in other countries or regions with which trade exists or could exist. One of the practical contexts in which competitiveness is discussed is the relative attractiveness of various countries as locations for developing a given sector. An alternative way to assess sectoral competitiveness includes comparisons with other industries in the same economy. While in a closed economy it is meaningful to examine the competition for human resources and capital between industries, growing globalization makes it more rational to consider the competition within the same industry between nations. Therefore, at the sectoral level competitiveness is usually linked with international trade performance. Markusen (1992) suggests the following trade-based definition of industry competitiveness:

In a free-trade environment: (1) An industry loses competitiveness if it has a declining share in total domestic exports or a rising share in total domestic imports deflated by the share of that good in total domestic 
production or consumption; and (2) An industry loses competitiveness if it has a declining share in total world exports or a rising share in total world imports of that good deflated (divided by) the country's share in world trade.

Yaacob (2007) gave a similar definition according to which meso-level competitiveness is the comparative advantage of an industry or a country, and also the ability of an industry to gain and maintain domestic and export market share.

Various indicators for total or net exports (revealed comparative advantage indices-RCAI) are commonly used to assess sectoral performance in foreign trade and determine whether country's industries possess comparative advantages.

Despite its clarity, the use of foreign trade performance as a competitiveness indicator raises other issues. For this reason, some authors like Markusen (1992) prefer to study an industry's competitiveness by comparing its productivity with that of the same industry in major trading nations. That author considers a sector competitive if it has a total factor productivity equal to or higher than that of its foreign competitors or if its average cost per unit of production is equal to or lower than that of its foreign competitors (Markusen, 1992).

Representing the relationship between output and input, productivity is an indicator of production efficiency. Since quantifying it is rather difficult, many studies focus only on a single factor of production, usually labor. Labor productivity is the ratio between total output value and the number of workers. Comparing a country's sectoral labor productivity with that of trade partners requires sector-level purchasing power parity data. For this reason, the growth rates of productivity are all too often compared rather than its levels (European Commission, 2009a).

Unit Labor Cost (ULC) is a frequently used indicator of an industry's competitiveness. It represents the ratio between wage rate indices and production indices (the value of final output). It is noteworthy that it is precisely relative labor costs per unit of output which are the relevant indicator for measuring price competitiveness, rather than solely differences in pay levels, since gains from international trade stem from comparative, rather than absolute advantages. If a real wage increase in a sector is accompanied by a commensurate productivity rise, the ULCI index remains unchanged. Real wage uptick implies that the opportunity cost of labor used in the industry has grown; i.e., other industries are bidding up the price of labor (or more generally that of production factors). In such a case, ULCI rises might reflect a shift of comparative advantage to other industries within an economy.

The definition of competitiveness at a sectoral level and its quantitative evaluation used by the European Commission, combine definitions and indicators based on foreign trade performance with those based on productivity and labor costs. The European Commission (2008) sees competitiveness at a sectoral level as the performance of a given industry within a country or region relative to the same industry in other countries or regions. A sector could be characterized as competitive on the basis of its capacity to grow, to innovate, and to produce more and higher-quality goods and services, and to keep or gain market shares in international and domestic markets (European Commission, 2008). In the EU Industrial Structure: Performance and Competitiveness report competitiveness, seen as a multidimensional concept, is defined by reference to two types of indicators. The first measures directly relevant aspects of competitiveness such as labor productivity and unit labor costs. The second type addresses international competitiveness by 
observation of sectors' performance on international markets. This involves analyzing the dynamics of Revealed Comparative Advantage (RCA) and Relative Trade Balance (RTB) indices and EU sectors' world market shares (European Commission, 2009b). These indicators (production index, labor productivity, labor cost per unit of output, RCA, and RTB) are presented as sectoral competitiveness indicators in the statistical annexes to several European Commission European Competitiveness Reports (European Commission, 2006; 2007; 2008).

The Ministry of Economy and Energy's 2007 Analysis of Bulgarian Industrial Companies' Competitiveness (in Bulgarian) does not give a definition of competitiveness (Ministry of Economy and Energy of the Republic of Bulgaria, 2007). Competitiveness indicators included in it are based on productivity (here the authors include indicators like labor productivity, labor cost productivity, the ratio of personnel costs to output, and labor costs per employee) and profitability calculated using the share of gross operating surplus in gross added value and profit rates in the sectors under observation. To enable sound recommendations for boosting competitiveness, however, sectoral analyses include overall characteristics and sectors' place in manufacturing, growth dynamics and scale, share in total employment, investment, technological levels and innovation, domestic market, foreign markets, EU regulations, standards, strategic and programming documents, role and activity of trade associations, strengths and weaknesses, and summaries of sectoral problems, in addition to the abovementioned indicators.

Analyzing the competitiveness of Central and Eastern Europe (CEE) on a sectoral level the authors of the Vienna Institute for International Economic Studies (WIIW) used the following indicators: labor productivity; labor cost per unit of output; investment growth; attractiveness for FDI; production dynamics; export growth and European market share growth; RCA and pattern of export specialization according to classification of industries based on factor intensity; and output quality indicators, based on comparison of export unit values (Havlik \& Landesmann, 2001).

Depending on statistical data availability, the indicators set out above could be used in an analysis of the overall competitiveness of Bulgarian industrial sectors. This is not to underestimate the complexity of competitiveness and the fact that it remains an ever relative concept that expresses a sector's ability to boost productivity and quality and to compete with analogous sectors in regional and global markets.

\section{Results of the Assessment of the Competitiveness of Selected Bulgarian Industries}

The industries addressed in the research are among Bulgaria's most promising sectors. Each of them has a significant share in total national exports, with their combined share in Bulgarian exports in recent years hovering at 70 percent. Recent years' sectoral analyses rank metallurgy, machine building, chemicals, clothing and textiles, furniture, wine production, tobacco, and food processing industry among Bulgaria's most competitive industries.

\section{Metallurgy}

In recent years, manufacture of metals and metal goods has occupied a growing share in Bulgarian output and added value. The industry has very dynamic production and sales volumes. The high share in the country's industrial output and in total goods export and the surplus generated in metals and metal products trade are important factors in improving Bulgaria's macroeconomic indicators. Metallurgy is thus seen as a key strategic sector in Bulgaria's economy. 
At the same time, diverse negative factors are facing the Bulgarian metals industry posing a number of challenges. Attaining the following aims ought to be a priority for all companies in the industry:

- Acquiring new knowledge;

- Introducing modern techniques and technologies to reduce energy intensity and to comply with the European environmental standards;

- Increasing investment in modern machines and facilities;

- Boosting the proportion of high-quality end products which would lead to sustainable increases in companies' competitiveness;

- Implementation of innovative solutions for manufacturing of new higher-value-added products and boosting workforce qualifications;

- Improving labor conditions.

\section{Machine Building}

Alongside being an industry which creates a relatively high added value, machine building has an intensive spillover effect across other sectors. This, together with accumulated tradition and production facilities, makes it particularly promising for Bulgaria's manufacturing and export specialization. Machine building is also an industry that relies largely on export markets for selling its production. Long traditions, good price/quality ratios, and good workforce availability among other factors contribute to the sector's competitiveness.

In spite of these distinct advantages, Bulgarian machine building also faces a number of challenges and difficulties on the road to improvement and enhanced competitiveness: low labor productivity; competitiveness, established in lower market segments, based on low costs in machines of only fair added value; a shortage of financial resources for investment in fixed assets and technological innovation; and insignificant inflows of FDI among others.

Bulgarian companies in the sector need to improve their management and turn to strategic long term development that involves a transition from comparative advantages reliant on low labor costs to specific advantages stemming from diversified goods and services with high quality and greater added value. Competitiveness could be boosted by:

- Active company policies for modernization of manufacturing technology;

- Firms' strategies should be directed to introducing and spreading innovation, regardless of how it is acquired - through transfer or own creation by closer interaction with research institutes and universities and higher R\&D expenditures;

- Improvement of the marketing approach applied. Companies should see that their products match to a greater extent the requirements set by the market;

- Development of entering new markets, while taking into account the efficiency of the logistic chain;

- Establishing modern human resources management systems; investment in human capital formation;

- Achieving synergy due to the establishment of long-term partnerships through creation of entrepreneurial networks, subcontractor chains, joint ventures with Western companies, clusters, etc.;

- Absorption of the grants allocated for co-financing of projects under the Competitiveness Operational Program and the Human Resources Development Operational Program as well as other programs funded by the $\mathrm{EU}$ and the state. 
Ultimately, to improve their competitiveness and to gain stable market positions in the global market, the efforts of the Bulgarian machinery companies should be focused on increasing the resources productivity and climbing up the ladder of added value through technological innovation, creation of innovative capacity, and formation of highly-skilled human capital.

\section{Chemical Industry}

Chemical industry is among the modern fast-developing sectors of the national economy. It is among the main carriers of the scientific and technological progress and it appears to be a significant factor for production intensification. This sector holds the potential to be the main engine of the economic growth as new technologies are continuously implemented and new products are developed. The chemical industry is also characterized by high export orientation, while large part of the companies occupy stable positions and are traditional players not only in the Bulgarian market, but also in international markets. The main competitive advantages of the industry are the good combination of quality and price, the flexible operations management, and high growth rates of added value. At the same time, there are barriers to the development of the sector's competitiveness, such as the considerable resource and energy intensities of the production, the prevailing share of raw materials and intermediate products in the export list, the added value still being low and the issues related to the quality management system.

In this regard, the recommendations for enhancement of the competitiveness of the companies operating in the chemical industry are in the following directions:

- Increase in production of goods with higher added value (intermediate and consumer products) that should have a prevailing share in the national export list;

- Implementation of new technologies to enhance the efficiency and reduce energy intensity;

- Maintaining and stepping up positions in the domestic market in spite of the increased competition and stabilization of sales on external markets; organization of manufacture designated to replace import;

- Increasing positions in the markets within the EU and beyond as well as occupying some new niches thanks to good price/quality ratio;

- Elaboration of joint programs between scientific organizations and companies from the industry designated to train sufficiently large number of highly skilled specialists;

- Stressing also on the non-price factors for competitiveness, inter alia, regulatory requirements and standards;

- Priority orientation towards biotechnological manufactures, production of perfumery and cosmetics, and of other light chemical industry products;

- Undertaking measures to assist the application process for EU programs through information campaigns and alleviating the red tape procedures so as to facilitate the participation in the EU operational programs and to benefit from the state mechanisms to boost export.

\section{Clothing and Textile Manufacture}

The recent years' developments as well as the present analysis have shown that currently the textile sector in Bulgaria has good competitive advantages in international markets. What limits the steady progress is the manufacture based on low added value and low production costs.

There are a number of cases, where, for the lack of a strategic vision for the enterprises' development, a peculiar downward movement along the spiral of the low added value is observed without any attempt to use 
the accumulated know-how and capacity, e.g., to develop own product for local and regional markets, to promote a brand and product diversification. Probably the current period is one of the key stages, under the conditions of post-crisis restructuring and unstable economic recovery, when the entrepreneurs mainly in the sewing sector in Bulgaria should undertake strategic steps to create higher added value or, on the contrary, to ensure in the short term new Cut, Make, Trim (CMT) orders and, respectively - to compete mainly on the basis of lower production costs, with other countries in the region or, at first sight unexpectedly and doubtlessly without any perspective, in Southeast Asia. In this context, the following recommendations for an increase in the sector's competitiveness can be highlighted:

- Need for strategic planning, which shall be a landmark for the enterprises' development in a medium-term perspective;

- Reorientation from CMT production to manufacture of products of higher added value;

- Building on the experience gained and the existing market positions of the Bulgarian manufacturers to develop and promote own brands;

- Proactive marketing to promote the Bulgarian companies' textile products in prospective niches in the domestic market and in the Balkan region's markets; diversification of the export markets by shifting to EU countries, other than our current partners (Germany, Italy, and Greece);

- Strategic partnerships with local and foreign contractors, including cooperation with or without equity participation;

- Development of a network of potential sub-suppliers and subcontractors in neighboring countries that have prospects for future EU membership;

- Strengthening the role of industry associations;

- Development of a capacity for design of models and own design, e.g. Computer Aided Design (CAD), Computer Aided Manufacturing (CAM) systems, including modernization of production funded by the EU Structural Funds;

- Maximum utilization of the most of the opportunities for manufacture of specialized production such as medical and military uniforms, etc..

\section{Furniture Manufacture}

Furniture manufacture is another export-oriented sector of the Bulgarian economy with proven traditions and qualities. In spite of its strengths, over the recent years the industry has faced certain obstacles that hinder additionally its development and slow its competitiveness growth. This entails low revenues, which is a reason for lower reinvested earnings and consequently hinders the replacement of machines and other fixed assets in the manufacture. Thus, the enterprises' productivity is additionally reduced. The insufficient profit is also a reason for Bulgarian companies to sell products with low added value - the margin is much lower as compared to that of a production, in which the end product design is widely used. When it comes to the export of Bulgarian furniture, the label "Made in Bulgaria" is not associated with high-quality production, neither with on-time delivery, which exerts a negative impact on the export of this type of manufacture.

The main competitive advantage of furniture manufacture in Bulgaria is the low remuneration level. However, even under these conditions, our country cannot compete with economies like China and India, which also rely on similar advantages. 
In the course of the analysis of the industry, the following recommendations can be outlined:

- Orientation towards products with higher added value which shall provide higher return for the enterprises and opportunities for more investment, respectively;

- Use of professional designers' services so that the Bulgarian furniture manufacturers shall differ from their foreign competitors, rather than imitate an already existing design;

- Strengthening the role of existing partner organizations (clusters) and establishing new ones so as to facilitate entering and strengthening positions in new markets, cooperating in joint advertising, marketing, and scientific research activities, and improvement of the access to crediting;

- Targeting wealthier market segments while retaining a good price/quality ratio;

- Updating educational curricula according to market requirements; training marketing and management specialists, which are of crucial significance for the successful entrance and establishment on foreign markets;

- Incentives provided by the government to boost competition between companies through innovation of end products, manufacturing processes and services;

- Increasing state incentives for the introduction and implementation of international quality standards.

\section{Wine Production}

Bulgaria has developed traditions and culture in vine growing and winemaking for centuries. Over the recent years a trend has been observed towards establishment of modern wine cellars which meet global standards as well as towards production of exclusive wines which compete successfully with proven world brands. In spite of the sector's progress so far, some additional actions and efforts are necessary to increase the competitiveness of this traditional for Bulgaria sector.

With regard to this, the wine producers and the National Vine and Wine Chamber should unite their efforts in order to strengthen the competitive advantages of Bulgarian wine - starting from the centuries-old tradition and considering the new vineyards, the change of the grape varieties, and creation of boutique wine series that shall turn into the image of the Bulgarian wine production. More and more producers and technologists with modern views realize that a fastidious European consumer can be attracted only by high-quality wines, even if not in large volumes. Therefore most of the new wine cellars aim at making high-quality wines and some of them really do. In the near future, if grown in appropriate areas, while the yield is controlled with care and the product is well marketed, local brands as Mavrud, Rubin, and Melnik can create a modern image of Bulgarian wine and make it competitive.

The specific recommendations for the sector's competitiveness enhancement are related to the following:

- Investment in the renewal of vine massifs, in technological development and innovation, and in human capital;

- Development of an efficient control system that shall cover the whole production process (from the vineyards to the bottle on the counter). The lawmaking bodies, industry associations, the producers and consumers' organizations should be involved in this process;

- A targeted policy to boost export (e.g., advertising, promoting, and positioning Bulgarian wine in the markets of third countries with a focus on its origin);

- Production of high-quality wines from the higher price segment (e.g., boutique wine series) designated for the solvent consumers in Western Europe;

- Strengthening positions on new markets as Brazil and entering potential markets-mainly countries in 
North and South America and Asia;

- Measures undertaken by the State and various institutions to support the absorption of the finances provided by the EU funds, mainly aimed at coping with red tape and corruption practices in the project application and approval process; shortage of funds for project co-financing and lack of sufficient information.

\section{Tobacco Industry}

The production and export of Bulgarian tobacco and tobacco products are a sector with established traditions, long history, and high level of competitiveness. Given the fact that the central position in the companies' structure of today's Bulgarian tobacco and tobacco products market is occupied by Bulgartabak-Holding $\mathrm{AD}$, which also monopolizes the export in the industry, the conclusions, and recommendations as regards the tobacco industry in the country have been drawn on the basis of an analysis of this company.

Bulgartabak - Holding AD has kept its competitive advantages thanks to the high-tech equipment, strong and established own brands on the domestic and external markets, developed distribution network as well as to the long traditions in the sector. In spite of the fierce competition with multinational companies, Bulgartabak-Holding $\mathrm{AD}$ is a leader on the domestic cigarette market. In the future the company's market share may remain stable as excise duties have already been increased, and the multinational companies' marketing strategies are no longer so aggressive. In the new post-privatization conditions, export appears to be crucial to the holding's growth.

As a result of the analysis, the following recommendations for enhancement of the sector's competitiveness have been pointed out:

- Flexible policies as regards the products' adaptation according to the preferences of the consumers both in the domestic and external markets;

- Training of specialists in the field of marketing;

- Marketing strategies for retaining the market presence of Bulgarian brands in the domestic and external markets to the greatest extent possible;

- Strengthening the existing positions in external markets and diversifying export destinations;

- Need to find new business partners and establishing own channels for selling abroad; elimination of the sector's dependence on intermediate companies in the international business operations;

- Effective measures to be undertaken by the state to cope with illegal trade and the continuous increase in smuggling;

- Development of innovative and modified products (product portfolio, design, color, flavor, taste, and packing).

\section{Food Industry}

The food industry is a highly-developed sector with rich traditions and has a significant role in Bulgaria's economy and export. On the basis of the research and the results thereof, the following basic conclusions and recommendations for the improvement of the state's economic policy as regards the export-oriented companies which aim at enhancing the quality of the business environment and the Bulgarian companies' export competitiveness have been formulated:

- Implementation of aggressive marketing policy, which includes creating a positive image of the Bulgarian goods on the domestic market as well as drafting and implementing strategies to promote branded Bulgarian 
food products;

- Establishing a common vision of the Bulgarian food industry based on quality and an attractive image;

- Establishing structures of clusters and improving the existing inefficient ones in the industry;

- Building cooperation and partnerships to exchange information about the markets and the challenges facing the food industry;

- Creating and promoting new organic food products in the market;

- Investment in new technologies and modern equipment to enhance the effectiveness and efficiency of production;

- The opportunities for access to EU financing remain underestimated and underutilized by the Bulgarian food industry companies;

- Seeking opportunities and undertaking measures to increase the share of export-oriented products with high added value in the total output of the food processing industry.

\section{Conclusions and Recommendations}

The different sectors of the Bulgarian economy have seen an uneven development since 2000. In the period of high economic growth, the greatest increase in output and attracted investments occurred mainly in the construction and financial sectors, which caused a considerable structural imbalance. The unstable financial environment and the subdued investment activity as from the beginning of 2009 affected those very sectors. Later on the changes due to the economic recovery of the main trade partners of Bulgaria provided favorable opportunities for development of the export-oriented sectors. This effect can be retained through adequate measures for enhancing the sectors' competitiveness. These measures should cover the legal regulations, tax system, investment in new equipment, infrastructure, human resources, and $\mathrm{R} \& \mathrm{D}$. The relevant industry associations can play a key role as a mediator between the state and the individual companies.

Taking into consideration the conclusions from the detailed study of the selected sectors, it can be summarized that for most of the export-oriented industries the following strengths are observed:

- Long-standing tradition in manufacture and export;

- More and more companies from the sectors under consideration rely on their good price/quality ratio to be their competitive advantage;

- Good price/labor productivity ratio;

- High extent of integration within the internal market which is evident from the fact that most of the exported production is oriented to EU markets;

- The geographical proximity to the main markets of the Bulgarian production guarantees short-delivery periods;

- Access to EU funding.

Despite the abovementioned advantages of the export-oriented sectors in Bulgaria under consideration, certain issues and challenges facing the industries can be specified as follows:

- Notwithstanding the apparent trend which has shaped over the recent years and the aim of Bulgarian goods to attain higher added value, its level remains unsatisfactory. The low profitability makes it impossible to invest in development and implementation of new technologies;

- Out-of-date production facilities and low extent of technologization, slow implementation of new technologies; 
- High energy intensity of production;

- Low labor productivity;

- Excessive dependence on cheap workforce, however, the importance of this factor is anticipated to gradually decrease in the near future;

- Gap between demand and supply of high-quality labor resources;

- Lack of a common strategic vision among industrial associations;

- The marketing components are insufficiently used;

- Low level of expenses for R\&D and unsatisfactory innovation activity;

- Competitiveness established mainly in low market segments;

- Underdeveloped infrastructure which hinders processes that require timely deliveries;

- Poor development of cluster formations;

- The strong link between the export-oriented sectors in the economy and the Euro zone is the cause for the decrease in external demand given the deteriorating economic situation in the leading trade partners of Bulgaria.

All these challenges facing the export-oriented sectors call for outlining and undertaking clear and appropriate measures so as to enhance and strengthen their competitiveness. This is a pressing issue that requires fast response and special attention, having in mind the great significance of the sectors at issue for the Bulgarian economy's growth. With a view to a higher level of competitiveness, the following recommendations could be given to the producers in these leading export sectors:

- Increase productivity by adding value growth at a faster rate than that of production costs as well as compared with the countries regarded as competitors. To that end, the companies can establish state-of-the-art logistics systems for fast deliveries, restructure the production so as to offer goods with high added value, and enhance marketing of Bulgarian goods;

- Upward movement along the supply chain (design) and downward movement in terms of marketing and trade are appropriate strategies for the success of the exporting companies. Despite the difficulties, Bulgaria can conduct trade successfully, especially in Eastern European markets;

- Investments in implementation of new technologies and transfer of technologies through FDI;

- Investments in R\&D, strengthening cooperation with scientific institutions;

- Establishing strategic partnerships both with local and foreign companies. An important element of cooperation between Bulgarian and foreign companies is that it should be carried out on the basis of intensive innovation. This suggests efficient use and implementation of knowledge, skills, and experience already gained by the foreign companies in production of new technologies, products, and services;

- Establishing clusters to increase added value, reduce costs, and enhance the competitiveness of companies in the sectors at issue. This, in turn, will make Bulgarian companies competitive on external markets where demand is larger - a task which is beyond the power of a single company;

- The necessary export diversification is to be achieved through extending the scope of the markets serviced and the product lines offered. This would allow the companies to respond adequately to the changes in international markets and to optimize the results of their foreign trade operations by efficient use of the international environment. To that end, it is necessary to examine not only the current export directions, but also non-traditional markets and their potential, to identify the goods in which the sectors have export advantages or export potential; 
- Creating conditions for training managers, designers, and other specialists, who shall acquire managerial and professional competence necessary for management of the sector's supply chain. With regard to this, Bulgarian companies should pay more attention to on-the-job training and should endeavor to up-skill their employees continuously;

- It is necessary to draft an export strategy directed, inter alia, to meet quality management requirements. Exporting companies in these sectors should guarantee that their products comply with the mandatory technical specifications set by the markets abroad and with the internationally recognized standards related to health protection, consumers' safety, and environmental protection. With a view to the demanding European market, where a prevailing fraction of the Bulgarian goods' export is oriented to, certification and implementation of the required quality standards should not be downplayed, on the contrary, they should be focused on;

- Management of the competitive advantages through the following: Formulation of a clear vision and strategy for establishment and maintenance of sustainable competitive advantages, which implies that the owners and company management should have a clear and precise understanding of the essence and the factor dependence of these competitive advantages; strategic analysis with a stress on resources. In the context of the strategic analysis, it is also important to perform a comparative study and analysis of the competitors' capabilities (benchmarking). It is the comprehensive information about the competitive advantages of companies from other countries offering the same, similar, or substitute products that will improve Bulgarian companies' awareness and help them make the right strategic decisions. The next group of activities related to the competitive advantages management implies planning concrete managerial and executive activities as well as relevant resources and organizational support. As is the case with strategies in general, in this particular case feedback, flexibility, and effective change management are again of importance.

Although the responsibility for the competitiveness lies mainly with the companies in the sectors, addressees of recommendations are another two groups of stakeholders - central and local authorities and institutions for cooperation (industry associations, educational, and training institutions).

The contribution of the state in the process of establishing stronger competitive positions of the Bulgarian export-oriented industries may cover the following areas:

- Laying stress on the educational system and its improvement is an important step towards increasing the level of competitiveness of the industries under consideration. The state, in particular higher educational institutions, should prepare their curricula in compliance with the real needs of businesses. A concrete step in this direction shall be the strengthening of the dialogue between them;

- Support for innovation and development activities, technological upgrading, establishing contact with engineering organizations, implementation of new technical and technological solutions as well as state-of-the-art business models. This would assist companies in continuously enhancing their capacity, identifying, choosing, and adapting successfully adequate technological solutions in their activities. In this context, opportunities will be sought to encourage applied research and its commercialization as well as the use of EU good practices;

- The main task of the State should be providing support to Bulgarian exporters through the following: preparing and providing the necessary business information, marketing research of foreign markets, technical support for establishing contacts, participation in fairs, business forums, advertisement of Bulgarian goods abroad and, as a whole, presentations of the Bulgarian economy in other countries to strengthen the presence of the Bulgarian producers and to improve the image of the country; 
- Measures aimed at establishing attractive conditions for FDI, including the following: fiscal incentives - corporate tax relief, temporary tax exemption, reliefs for funds used for investment and reinvestment, an accelerated depreciation regime, reliefs in case of R\&D-related activities, etc.; financial incentives - state subsidies to cover a fraction of the start-up costs, credit reliefs or guarantees, providing favorable state insurance conditions; other incentives-public expenditure for establishing investment infrastructure, creating areas of special economic status, etc.;

- Introducing effective labor legislation and a flexible labor market;

- Supporting promising export-oriented sectors through a comprehensive national strategy for export boosting. The export strategy should position the country in international markets, while identifying on a regular basis, the competitive Bulgarian products and product groups. Its main role is to focus and unite the efforts of the state agencies and institutions whose job is to promote Bulgarian export as the Bulgarian Smalland Medium-size Enterprises Promotion Agency, Bulgarian Export Insurance Agency, Bulgarian Development Bank, InvestBulgaria Agency, and the country's trade missions abroad.

In the context of the current strained economic situation, when the changes in the macroeconomic environment are chaotic and unpredictable and the achieved results are not attractive enough for investors, producers, and exporters, a policy of particular incentives for production and export has to be introduced. It is true that, due to the tight domestic market, it is precisely the export-oriented sectors that generate growth in the Bulgarian economy, but this is only when they are competitive on international market. The negative consequences of the economic crisis influence the competitiveness of the promising industries and the entire economy, respectively. This urges the state to attach particular attention to this issue and to direct considerable efforts and funds to find its solution. State support for the priority economic sectors will trigger a revival in the rest of the industries and, consequently, in the national output as a whole. The state support is to provide the conditions for new export-oriented manufactures that shall prove and strengthen the image of Bulgaria as regards the groups of goods with high added value. This implies implementation of policy of production integration with EU countries and the other developed countries in the field of new technologies.

The policy of broadening the access of Bulgarian goods to world markets should be combined with policies aiming at attracting foreign investment to national export-oriented manufactures. The aim is to make their presence on these markets as well as the competition with the foreign products on the domestic market successful. By drafting sectoral export strategies, conditions shall be created for combining the stakeholders' efforts for enhancement of enterprises' export competitiveness and for the implementation of effective policy to boost export.

The institutions for cooperation also play a significant role for the enhancement of the export-oriented industries' competitiveness.

(1) The sectoral organizations can assist in solving the pending issue of the highly-skilled workforce shortage facing most of these sectors in the following way:

- Drafting programs for up-skilling and on-the-job training and more active implementation of the lifelong learning concept in the practice of the economic agents;

- Playing more active role in updating the curricula of the specialized schools and higher education institutions that need better compliance with the requirements and needs of the companies of cadres with certain professional skills;

- Drafting and execution of various initiatives to enhance the sectors' attractiveness for professional 
development among young people;

- In order to overcome the information imperfections on the labor market, the industry associations need to establish information systems for demand and supply of specialists in the relevant sectors.

(2) The main issue facing the Bulgarian companies is the low labor productivity, which is due to the use of out-of-date production capacities and technologies. The industry associations contribution in this respect implies the following:

- Providing competent consulting services to enterprises for developing projects of good quality to apply under EU operational programs with the purpose of better use of the opportunities for technological modernization of the small and medium enterprises (SMEs) and implementation of innovative processes and products;

- Assisting in acquiring licenses for foreign technologies, transfer of know-how and knowledge;

- The industry associations need to serve as an intermediary between the universities, scientific institutes, and businesses for the purpose of enhancing the enterprises' innovation activities.

(3) Industry associations have an indispensable role in assisting member companies in entering international markets. In particular, this can be realized through: collecting, summarizing, and providing information on the opportunities and the ways for entering particular foreign markets, the existing regulatory regime, and the general economic situation; helping companies participate in significant events, where they can establish contact with potential partners-fairs, conferences, exhibitions, competitions, etc.

(4) In today's global economy the competitiveness of industries does not depend only on the combined competitiveness of all companies. It is now to a greater extent dependent on the companies' capabilities to cooperate with potential partners from related industries, on the complexity of company services (consultations, $R \& D$, financial services, etc.), on the efficiency of public administration, and on political decisions, which support the establishment of favorable business environment for economic development. In this regard, the role of industry associations is to assist in overcoming the distrust among their members, to help them realize business cooperation, and participate in clusters;

(5) The main efforts of the industry associations should be aimed at assisting businesses in adoption, implementation, certification, and control of the multitude of European rules, standards, and directives.

In conclusion, it is important to note that under market economy conditions economic agents are the ones who create national welfare and ensure competitive sustainable development. Therefore, despite the unique role of the assisting organizations and the state support, including the state export strategy, without the effective operation of the business units, the enhancement of the international competitiveness is impossible.

\section{References}

D’Cruz, J., \& Rugman, A. (1992). New compacts for canadian competitiveness (p. 14). Toronto: Kodak Canada. European Commission. (2001). European competitiveness report 2001. Commission Staff Working Paper, Brussels. European Commission. (2006). European competitiveness report 2006. Commission Staff Working Paper, Luxembourg. European Commission. (2007). European competitiveness report 2007. Commission Staff Working Paper,Luxembourg. European Commission. (2008). European competitiveness report 2008 (p. 106). Luxembourg.

European Commission. (2009a). EU industrial structure 2009: Performance and competitiveness (p. 94). Luxembourg: Publications Office of the European Union.

European Commission. (2009b). EU industrial structure: Performance and competitiveness (p. 180). Luxembourg: Publications Office of the European Union.

Havlik, P., \& Landesmann, M. (2001). Competitiveness of industry in CEE candidate countries. Vienna: WIIW. 
IMEDE. (1991). World economic forum (p. 8). The World Competitiveness Report 1991.

Kubiak, A. (2006). On essence and measurement of changes in competitiveness of the accession countries: Critical review of literature. Studies and Analysis, 321, 1-30.

Markusen, J. (1992). Productivity, competitiveness, trade performance, and real income. Ottawa: Economic Council of Canada for Minister of Supply and Services Canada.

McFetridge, D. (1995). Competitiveness: Concepts and measures. Occasional Paper 5, Industry Canada, Toronto.

Ministry of Economy and Energy of the Republic of Bulgaria. (2007). Analysis of the Competitiveness of Bulgarian Industrial Coтрапіеs (Министерство на икономиката и енергетиката на Република България, Анализ на конкурентоспособността на българските промишлени предприятия). Retrieved from http://old.mi.government.bg/bids.html?id=134456

Momaya, K. (1998). Evaluating international competitiveness at the industry level. The Journal for Decision Makers, 23(2), $39-46$.

UNCTAD. (2004). Trade and development report (p. 135). New York: UNCTAD.

World Economic Forum. (2010). The global competitiveness report 2010-2011 (p. 4). Geneva, Switzerland: World Economic Forum.

Yaacob, H. (2007). The study of export competitiveness of Malaysian electrical and electronic product. Shah Alam: UiTM Press.

Zaharieva, G. (2007). Measuring national competitiveness. Svishtov, Bulgaria: D. A. Tsenov Academy of Economics. 